\title{
Models of work in collaborative economy and legislative challenges
}

\author{
Silvia Trel'ová1,** \\ ${ }^{1}$ Comenius University in Bratislava, Faculty of Management, Odbojárov 10, 82005 Bratislava 25, \\ Slovak Republic
}

\begin{abstract}
.
Research background: Globalization, the development of technology, demographic change are phenomena that radically change the nature of work. The advent of modern information technologies represents a worldwide transition to the information society, and the ubiquitous technological development brings ever newer forms of working. The development of a sharing (collaborative) economy is global in nature. A wide range of models for carrying out work with the help of digital collaborative platforms is created and a natural person in the position of a service provider performs activities with a high degree of independence and flexibility. There are several collaborative platforms but not all of them show the characteristics of a pure sharing economy, and there are considerations as to whether, in some cases, there is no concealment of employment relationships.

Purpose of the article: The author points out various models of collaborative economics, compares them and assesses the nature of the work performed. Based on the findings, the author concludes whether the person performs work in a commercial relationship or whether this work can be perceived as dependent work in terms of labour law.

Methods: Models of collaborative economics need to be analyzed and compared. The induction method is used in the examination of individual court decisions. The conclusion is a summary of the acquired knowledge.

Findings \& Value added: The issue is highly topical due to the ambiguity of the nature of work relationships. In practice, this is evidenced by several lawsuits. The article will contain proposals de lege ferenda.
\end{abstract}

Keywords: collaborative economy; sharing economy; collaborative platforms; flexible work

JEL Classification: $A 12 ; \mathrm{K} 12 ; \mathrm{L} 26 ; \mathrm{O} 1$

\footnotetext{
* Corresponding author: silvia.trelova@,fm.uniba.sk
} 


\section{Introduction}

The advent of the information society and information technologies is associated with the term "the New Economy", which is a combination of a new form of organization and decision-making processes of economic entities in conjunction with technological and nontechnological innovation and human resource development. Although there is no uniform definition of the term new economy, the professional public emphasizes the importance of new technologies and knowledge in this regard. As Baláž and Verček point out, the new economy covers specific types of economies - post-industrial economy, innovation economy, knowledge economy, network economy, electronic economy (e-economy), internet economy (internet-economy) [1], whose driving force is changes of a technological nature. "The development of technologies for online business led from market and trade fairs to smartphones." [2] The mass spread of information and communication technologies (ICT) and fast internet connections are changing both the form and manner of communication of persons, as well as the functioning of economic entities.

In recent years, the development of a sharing (collaborative) economy that is spreading across Europe is a modern phenomenon. This type of economy (sometimes referred to as co-consumption or collaborative consumption $[3,4]$ ) is global in nature, as the sharing of services and assets, which are the essence of this economy, is becoming accessible to all. For consumers, the popularity of the shared economy is based not only on cost saving, but comfort and time savings can also be the motive of consumers. [5] „No less important reason is the philosophical aspect, which is consistent with efforts to promote more sustainable consumption practices that prioritize access over ownership." [6] Collaborative consumption is underlying by the consumers' attitudinal beliefs about cost savings, efficient use of resources and the community with others. [7] This model of the new economy is based on sharing, lending, exchanging or renting assets (asset $=$ goods or service that serves to meet human needs) through the use of web technology - a web or mobile application or website. Modern technologies, which make it possible to share practically anything and with anyone, are a key element of transactions in satisfying demand on the basis of supply. „Indeed, the new technologies through the digital platforms have come to increase the links and the contact of the people who wish to exchange all kinds of products and services." [8] ICT ensures low-cost transactions, the use of non-cash payments by users, the visibility of references (satisfaction / dissatisfaction) of users (customers). Gansky L. states that ,sharing businesses share four characteristics: "sharing, advanced use of Web and mobile information networks, a focus on physical goods and materials, and engagement with customers through social networks" $[9,10]$.

\section{Methods}

The methodology is based on distinguishing and comparing models of collaborative economics and defining the status of the sharing company and the service provider in the performance of work from a legal point of view. The method of analysis and comparison is used in the characteristic of the position of entrepreneur and employee. The focus of this paper is the case of sharing company of the type property-based services. In relation to this type of company, we assessed the nature of the working relationship between the sharing company and the service provider. Through case law, we have linked theoretical knowledge with application practice. Finally, due to the absence of legislation, we have formulated de lege ferenda proposals. 


\section{Theoretical background and practice}

\subsection{Resolution criteria and models of sharing economy}

Sharing economy can be defined as an economic model that supports the use of ownership and allows the optimization of consumption through sharing, exchanging (barter), renting and lending of goods and services. [11] Sharing is considered to be a phenomenon that connects consumers to each other for consumption.

The models of the sharing economy are different. In the professional public, there is a distinction between models of the sharing economy based on various criteria. In terms of ownership, certain goods can be shared through a modern technological tool directly from the company as their owner (an example is the already completed Bratislava project up!City, which has been operating since 2017) or they can be shared through the platform as an intermediary who is not the owner of shared goods (Uber, Lyft, Airbnb) - according to Gansky L. it is the "Full Mesh Model" and "Own To Mesh Model" [9]. Depending on the participants, sharing can take place between two individuals (person-to-person), between a company and a customer (business-to-consumer), or between two different companies (business-to-business) [12]. In addition to the nature of the participants, the sharing can also be distinguished depending on the nature of the goods (assets, estate). Such division is based on what is shared. Trippett, E. Ch. states that it is possible to share only property, combination of property and labour, or only labour. [10] Sharing companies can be divided into three categories - (1) property-sharing (e.g. Airbnb), (2) property-based services (e.g. Uber), and (3) service sharing companies (e.g. TaskRabbit, Amazon MTurk). [13] In the first category can be shared tangible property (movable and immovable) - flats, cars, clothes. The essence lies in the transfer of possession for a fixed period - rental service (e.g. renting tools, renting cars ...). In the second category of sharing companies, as Trippett E. Ch. states, the companies ,sell beneficial use of property by its owner on the customer's behalf" [13] (e.g. ensuring the transport of a person from one place to another using a vehicle owned by the driver as a service provider). We can say that, unlike the first category of sharing companies, the position of the second category of these companies is different because the company provides the service through another person. It is about performing work. „These organizations are digital platforms that combine physical and digital service elements." [14] The last, the third category, is just about virtual labour sharing (the term crowd work or crowd sourcing is used in the professional public), e.g. translations of texts, assembly or service, removal of furniture. In the case of this type of sharing company ,an individual service provider sells his or her labour (but not possession or beneficial use of property) to a customer of the sharing company." [10]

Based on the above, it we can state that the digital age creates a wide range of models of the sharing economy (collaborative economy), especially in the field of services that are becoming more available (a principle of mobile application). For example Milosovičová and Stachová are dedicated to the Slovak business environment in connection with the situation on the labour market. [15].

The Internet offers companies opportunities to use people more flexibly. Instead of building stable employment relationships, only very short-term contracts for the provision of individual services are concluded with service providers. In this context, the platforms play a very important role, because they create the connection between the mass of potential service providers ("crowd") and the customers of these services. [2] The sharing economy brings new forms of work that are evolving dynamically. However, this is grossly disproportionate to the legislative changes that respond to society's needs. Legal regulation 
in this area is insufficient, is lagging behind, we can even say that it is currently absent. Also Hossain M. in his study based on a review of sharing economy literature (219 articles) highlights the lack of regulations and policies for sharing economy around the world. [16]. Business models through digital platforms that are poorly regulated, even deregulated, compete with services that are traditionally highly regulated. [17]

\subsection{Business or dependent activity?}

The Slovak legal system also distinguishes between a citizen (natural person), an entrepreneur (natural person or legal person) and an employee (natural person). The performance of independent non-business activities is regulated by the Civil Code (Act No. 40/1964 Coll., the Civil Code, as amended), the performance of independent business activities is regulated by the Commercial Code (Act No. 513/1991 Coll., the Commercial Code as amended) and work is regulated in the Labour Code (Act No. 311/2001 Coll., the Labour Code, as amended). The right to gainful activity is enshrined in the Constitution of the Slovak Republic (Constitutional Act No. 460/1992 Coll., the Constitution of the Slovak Republic, as amended), which guarantees everyone's right to "a free choice of profession and to training for it, as well as the right to engage in business or other gainful activity" (Article 35 paragraph (1) of the Constitution of the Slovak Republic).

In order for an activity to qualify as a business, certain features must be met. These features are defined by the Commercial Code, which understands business as "systematic activity which is independently carried on, carried on by an entrepreneur in his own name and at his own liability (responsibility) and carried on for the purpose of making a profit or for the purpose of achieving a measurable positive social impact, if it is an economic activity of a registered social enterprise according to a special regulation" ( $\$ 2$ paragraph (1) of the Commercial Code). If the activity performed by a person does not fulfill any of these five characteristics of business, the Civil Code will apply. Such activity is not business activity.

Since not every activity is a work in the sense of labour law, the subject of employment relationships is in general the activity of a person who performances dependent work for another. The work which is the subject of the labour law, must meet certain legal characteristics, it must have certain typical features. Employee's work must be human, free, dependent, non-self-employed, performed for another, remunerated and tied exclusively to the employee. Dependency is an inherent part of the job performance for the employer.

The definition of dependent work is a fundamental concept of the labour law and denotes the work performed in the employment relationships. The Slovak legislation did not define the dependent work for a long time. The current legislation of the Labour Code defines dependent work as a work that is "carried out in relation to the employer's superiority and employee subordination, personally for the employer, according to the instructions of the employer, on his behalf, in the working time determined by the employer" (§ 1 paragraph (2) of the Labour Code). Regarding the performance of work, all above must be fulfilled (cumulativeness of 5 defining characters). If even one of them is missing, it is not a dependent work. Then this activity can be covered by a contract under the Commercial Code or the Civil Code.

As follows from the above definitions, the basic feature distinguishing an employment relationship from business is the personal subordination and economic dependency of the employee. Unlike the employee who is guided by the employer's instructions when performing work, the entrepreneur carries out his activity independently and decides alone what he will do, with whom he enters into a commercial relationship and with whom he does not. The employee voluntarily submits to the superior (employer), i.e. the employment relationship compared to other contractual types is not based on the principle of equality of 
the parties. The essence of relationship is based on the fact that the employer has the ability to manage the performance of the employee's work and, on the other hand, the employee is obliged to follow the instructions of the employer. These facts meet the definitive features of the term "dependent work", which can be considered as a starting differentiating criterion. Business, unlike dependent work, is an independent activity.

A large majority of companies in the sharing economy treats their contractual partners workers as independent contractors (for example Uber classifies their drivers as independent contractors). But is this approach correct? Should the sharing economy worker have the status of independent worker (independent contractor) or the status of employee?

We are of the opinion that the correct definition of the concept of dependent work in the legislation of labour law will prevent the efforts of employers to reduce the number of employees in the performance of dependent work and to establish business and legal relations with them. Although the definition of dependent work is a part of the legal order and legal culture in almost all EU Member States, "until now, no legal system has found clear and precise criteria under which it would be possible to seamlessly find out when it comes to the performance of dependent work [18], it means performance of such work, by the performance of which a natural person acquires the status of an employee and enjoys all the protective benefits offered by employment law to persons with this status [19]". In application practice, there are still uncertainties with the application of this term and these uncertainties are also in the area of sharing economy and are related to uberization (it is a case of sharing company of the type property-based services - see above Trippett). The service provider performs the work and therefore there is a legitimate interest from the point of view of labour law.

The work in models of sharing economy is performed through digital platforms and in this working model three entities take part - the collaborative platform in the position of mediator of services, the service provider and user of services as the receiver of service. The number of entities is the untypical element of a labour relationship, however, there are considerations that a sharing company could also have employer status.

It should be emphasized, that the choice of the right contractual form depends exclusively on the content of the work performed. Based on the legislation of the Slovak Republic, the rule applies: if the work has features of dependent work, the employment relationship must be concluded for the performance of such work and if the work does not have such features, it can be used the contractual relation in accordance with the Commercial Code or the Civil Code.

\subsection{UBER as a party to litigation concerning the status of drivers as service providers}

Under the influence of the development of ICT, not only new forms of mediation have been created, but also increasingly complex working relationships have been established. When we look at the status of the service provider, in the different models of sharing economy his status is either a self-employed person (enterpreneur) or an employee. Although workers in the sharing economy are overwhelmingly classified as enterpreneurs - independent contractors, we must emphasize here that in some cases the position of the service provider is ambiguous.

"These developments have often proved very controversial, as instanced by the disputes surrounding Uber, the international, internet-based taxi provider." [20] The lawsuits in various countries in which the American company for a shared ride UBER operates also show the ambiguity in the position of drivers. Even though Uber has long reasoned that it is only a platform which connects drivers and travellers (Uber perceives drivers as partner drivers), some judges are of a different opinion. We can point, for example, to London 
Labour Tribunal and Labour Appeal Tribunal in in proceedings Aslam, Farrar v. Uber, in which the court ruled that the relationship between the driver of the digital platform and the mediator of services (Uber platform) is an employment relationship. The court questioned the mechanism created by Uber for the purpose of creating the impression that the drivers are self-proprietors using the offered technology for better access to job opportunities. [21] Such decision is not the only one. The Supreme Court in France held a similar view of the employment relationship. In March 2020 this court decided that one of the former drivers was in fact an employee. The court reasoned in the decision by the fact that the company Uber had control of the driver through his connection to the application which led him to clients. This is the reason why the service provider should be considered an employee, not an independent subcontractor.

We identify with these decisions and we ask: If there is a work interview with the Uber drivers, if the route is given to the driver by an application, if Uber sets fixed prices of transportation, if drivers receive internal instructions, where is the high level of entity autonomy so typical for sharing economy? This verdict can be groundbreaking and can subsequently affect all Uber-inspired platforms.

\section{Results and Discussion}

In recent years, the development of a sharing (collaborative) economy has become a modern phenomenon and is spreading across Europe. This type of economy is global in nature since sharing services and property becomes available to all. Moreover, the fact that this phenomenon has been examined by various experts cannot be denied. "It has attracted scientists from a wide variety of fields and disciplines to the evolving research area. Given the diversity offered perspectives, it is very necessary to gather and link what has been done and to identify some common themes, which will serve as a basis for future discussions on the crucial roles played by digital platforms in the sharing economy." [22] Turbulent discussions are taking place in various directions. We are also looking for answers to questions related to concerning competition, protection of privacy, data privacy and security, discrimination, liability, workers' rights, etc. [23]

In our article, we focused on the legal area and provided a legal view of the contractual relationships arising from the performance of work. There are several collaborative platforms but not all of them show the characteristics of a pure sharing economy, and there are considerations as to whether, in some cases, there is no concealment of employment relationships in which service providers are deprived of employment rights in relation to intermediaries. Using the work of independent persons instead concluding an employment relationship is a common problem in application practice. The competition of contractual types of labour law, commercial law and civil law is not only a specific of the legal practice of the Slovak Republic. It is a current issue not only in the Member States of the European Union, but also in other countries of the world.

The development of new forms of work as a result of digitalization is developing dynamically, new legal situations are emergingand this should be also reflected in legal regulations of these working relationships which, however, is still absent. The legal regulation of some collaborative methods of work performance is unambiguous and in application practice new challenges arise, to which the legislation should respond. What legislative changes are needed and which fields of law they will cover, is the subject of professional discussions and analyses.

An important question needs to be answered: What legal regulation should cover these modern legal relationships arising from the performance of work activities? To get the answer, we need to analyze in real detail the various forms of sharing economy, compare them, assess the relationships between contractors of work and buyers of work. The answer 
is really not simple or completely clear. If we consider whether natural persons should perform these non-standard ways of performing work in the regime of labour law or commercial law, based on the analysis of this issue, we lean towards the first option. The reason is to maintain a certain protection of a natural person, both labour-law protection and social-law protection (existence of a maximum working time, existence of a minimum wage, health protection at work, providing catering or making a contribution, etc.). If the performance of digital forms of work were outside the employment relationship, the natural person would lose the rights following from labour law and social law. The problem of legal coverage of dependent work by commercial contract types (respectively civil contract types) would have an adverse economic impact in relation to tax obligations and entrepreneurs would be relieved not only of any obligations arising from employment relationships, but also from levy obligations.

We are of the opinion that the performance of work in digital form should be the subject of labour law and natural persons should form a relatively separate work category when performing digital form of work. As the category of employee and self-employed person is no longer sufficient, because a modern worker does not have the status of either a pure employee (typical employee) or a pure entrepreneur (typical entrepreneur), it is necessary to create something like an intermediate category between the term of employee and selfemployed person. Barancová $H$. also points at making the current definition of the term employee more flexible [24]. The Labour Code should expand the category of subjects of labour law and define the so-called economically dependent employees. "Such persons, similar to employees, do not belong to the category of employees or to the category of entrepreneurs from the point of view of personal competence." [25] Given their position the way they work and the degree of their independence, on the one hand they would not be protected in the same way as traditional employees, but on the other hand they would be protected more than self-employed persons.

We believe that it is necessary to enshrine a certain looser employment relationship through special provisions of the Labour Code, similarly as the Slovak legislation recognizes in connection with teleworkers or employees working on agreements on work performed outside employment relationship. Under this legislation, some working relations within digital platforms would be subsumed under the concept of dependent work, which would have a double effect: 1 . increasing the basic level of protection of affected workers and 2. avoiding the competitive advantage that each sharing company will gain in concealing employment relationships.

\section{References}

1. Baláž, P., Verček, V. (2002). Nová ekonomika a její postavení v globalizujícím se světovém hospodářství. Politická ekonomie, L(2), 156-167.

2. Wefers, J. (2019). Kollaborative Wirtschaft. Sharing Economy. Praha: Wolters Kluwer

3. Felson, M., Spaeth, J.L. (1978). Community Structure and Collaborative Consumption: A Routine Activity Approach. American Behavioral Scientist, 21(4), 614-624.

4. Belk, R. (2014) You are what you can access: Sharing and collaborative consumption online. Journal of Business Research, 67(8), 1595-1600.

5. Joo, J. (2017). Motives for Participating in Sharing Economy: Intentions to Use Car Sharing Service. Journal of Distribution Science, 15(2), 21-26.

6. Soltysova, Z., Modrak, V. (2020). Challenges of the Sharing Economy for SMEs: A Literature Review. Sustainability 2020, 12(16), 6504. 
7. Roos, D., Hahn, R. (2019). Understanding Collaborative Consumption: An Extension of the Theory of Planned Behavior with Value-Based Personal Norms. J Bus Ethics 158(3), 679-697.

8. Matar, L., Aoun, G. (2017). The Challenges and Opportunities of the Sharing Economy: The Case of a Developing Economy. In K. S. Soliman (Eds.), Vision 2020: Sustainable Economic development, Innovation Management, and Global Growth, (pp. 1952-1958). Norristown : IBIMA.

9. Gansky, L. (2012). The Mesh: Why the Future of Business Is Sharing. Reprint edition. New York: N.Y: Portfolio/Penguin.

10. Trippett, E.CH. (2016). Using Contract Terms to Detect Underlying Litigation Risk: An Initial Proof of Concept. Lewis \& Clark Law Review, 20, Forthcoming.

11. Botsman, R., Rogers, R. (2010). What's Mine Is Yours: The Rise of Collaborative Consumption. New York: Harper Business.

12. Puschmann, T., Alt, R. (2016). Sharing Economy. Business \& Information Systems Engineering, 58(1), 93-99.

13. Trippett, E.Ch. (2017). Employee Classification in the Sharing Economy. Cambridge Handbook of Law and Regulation of the Sharing Economy, forthcoming, 14.

14. Frey, A., Trenz, M., Veit, D. (2019). A service-dominant logic perspective on the roles of technology in service innovation: uncovering four archetypes in the sharing economy. Journal of Business Economics, 89, 1149-1189.

15. Milošovičová, P., Stachová, P. (2016). Slovak business environment in the context of the situation on the labour market. Innovation, management, entrepreneurship and corporate sustainability (pp. 457-468). Praha : Vysoká škola ekonomická v Praze.

16. Hossain, M. (2020). Sharing economy: A comprehensive literature review. International Journal of Hospitality Management, 87, 102470.

17. Blanpain, R. (2014). Subordinate Employees or Self-Employed Workers? (11. edition), Netherlands : Wolters Kluwer Law \& Business

18. Žulová, J. (2015). Oslabovanie znakov závislej práce vo vybraných pracovných vztahoch. Pracovnoprávne elementy výkonu (závislej) práce. Kritika a deformácia práva. Košice: Univerzita Pavla Jozefa Šafárika v Košiciach

19. Sanasi, S., Ghezzi, A., Cavallo A., Rangone A. (2020). Making sense of the sharing economy: a business model innovation perspective. Technology Analysis \& Strategic Management, 32 (8), 895-909.

20. Freedland, M., Prassl, J. (2017). Employees, workers and the 'sharing economy' Changing practices. Spanish Labour Law and Employment Relations Journal, 1-2(6), 16-29.

21. Vith, S., Oberg, A., Höllerer, M.A., Meyer, R.E. (2019). Envisioning the 'Sharing City': Governance Strategies for the Sharing Economy. Journal of Business Ethics, 159(4), 1023-1046.

22. Sutherland, W., Jarrahi, M.H. (2018). The sharing economy and digital platforms: A review and research agenda. International Journal of Information Management, 43, 328-341.

23. Etter, M., Fieseler, Ch., Whelan, G. (2019). Sharing Economy, Sharing Responsibility? Corporate Social Responsibility in the Digital Age. Journal of Business Ethics, 159(4), 935-942.

24. Barancová, H., Olšovská, A. (2018). Priemysel 4.0 a pracovné podmienky. Praha: Leges. 
25. Dolobáč, M. (2015). Zastretý pracovný pomer. Pracovnoprávne elementy výkonu (závislej) práce - Kritika a deformácia práva (pp. 30-39). Košice: Univerzita Pavla Jozefa Safárika v Košiciach. 